\title{
The Federal Reserve Is Not Very Constrained by the Lower Bound on Nominal Interest Rates
}

\begin{abstract}
I survey the literature on monetary policy at the zero lower bound (ZLB) and effective lower bound (ELB) to make three main points: First, the Federal Reserve's forward guidance and large-scale asset purchases are effective monetary policy tools at the ZLB/ELB. Second, during the 2008-15 U.S. ZLB period, the Fed was not very constrained in its ability to influence medium- and longer-term interest rates and the economy. And third, the risks of the Fed being significantly constrained by the ELB in the future are typically greatly overstated. I conclude that the Federal Reserve is not very constrained by the lower bound on nominal interest rates.
\end{abstract}

n December 2008, the Federal Reserve lowered the federal funds rate to essentially zero, where it remained until December 2015. Because U.S. currency carries an interest rate of zero, it is essentially impossible for the Fed to set the federal funds rate substantially below zero without triggering widespread conversion of deposits into currency. This constraint is commonly referred to as the zero lower bound (ZLB) —or as the effective lower bound (ELB), to acknowledge that the bound may be somewhat negative rather than literally zero.

The existence of the ZLB/ELB has led many researchers to conclude that it imposes a substantial constraint on the Fed's ability to conduct monetary policy in a low-interest-rate environment (Krugman 1998; Williams 2009; Kiley and Roberts 2017). In this paper, I survey the recent literature to demonstrate exactly the opposite: that the ZLB/ELB has not been, is not,

Conflict of Interest Disclosure: The author did not receive any financial support from any firm or person for this paper or from any firm or person with a financial or political interest in this paper. He is currently not an officer, director, or board member of any organization with an interest in this paper. 
and almost certainly will not be a significant constraint on the Federal Reserve-in the past, the present, or the foreseeable future. This conclusion follows from three main observations. First, the Federal Reserve's forward guidance and large-scale asset purchases are effective monetary policy tools at the ZLB/ELB; in fact, they are about as effective as the federal funds rate in normal times. Second, during the 2008-15 U.S. ZLB period, the Fed was not very constrained in its ability to affect medium- and longer-term interest rates and the economy. And third, the risks of the Fed being significantly constrained by the ELB in the future are typically greatly overstated.

\section{The Federal Reserve Has Additional Monetary Policy Tools Available}

The first main observation is that the Federal Reserve has other monetary policy tools available beyond just changes in the current federal funds rate. In particular, there is a large and growing body of literature on the effectiveness of forward guidance-that is, communication by the Federal Reserve about the likely future path of the federal funds rate over the next several quarters - and of large-scale asset purchases (LSAPs) which are purchases by the Federal Reserve of hundreds of billions of dollars of longer-term U.S. Treasury securities and mortgage-backed securities.

Theoretically, financial markets and firms are forward-looking, so firms' investment decisions depend not just on the current short-term interest rate but also on the path of expected future short-term interest rates over the next several years. A simple way to formalize this observation is with a standard New Keynesian investment/saving curve,

$$
\hat{y}_{t}=E_{t} \hat{y}_{t+1}-\alpha \hat{r}_{t}+\varepsilon_{t}
$$

which can be solved forward, assuming $\lim _{j \rightarrow \infty} E_{t} \hat{y}_{t+j}=0$, to get

$$
\hat{y}_{t}=-\alpha E_{t} \sum_{j=0}^{\infty} \hat{r}_{t+j}+\varepsilon_{t}
$$

where $t$ indexes periods, $\hat{y}_{t}$ is the output gap, $\hat{r}_{t}$ is the deviation of the one-period real interest rate from its steady state, $E_{t}$ denotes the mathematical expectation conditional on information at time $t$, and $\varepsilon_{t}$ is a mean-zero shock. The infinite sum in equation 2 illustrates how the Fed can affect 
the current output gap by changing people's expectations about the future path of $\hat{r}_{t+j}$ as well as the current value of $\hat{r}_{t}$ itself. David Reifschneider and John Williams (2000) and Gauti Eggertsson and Michael Woodford (2003) use this fact to show that, even at the ZLB, the Fed can still stimulate the economy as long as it can credibly commit to a lower path of short-term interest rates in the future, when the ZLB is no longer binding.

Empirically, Refet Gürkaynak, Brian Sack, and Swanson (2005, henceforth GSS) showed that changes in the federal funds rate alone were not sufficient to explain financial market reactions to announcements by the Federal Reserve Federal Open Market Committee (FOMC), and that there was a second dimension of monetary policy that was being missed. GSS developed a measure of forward guidance based on high-frequency changes in a range of federal funds and eurodollar futures contracts around FOMC announcements, orthogonalized to the change in the current federal funds rate. They showed that forward guidance had highly statistically significant effects on financial markets and dramatically increased the explanatory power of FOMC announcements for financial market responses. GSS also showed that large movements in their measure of forward guidance were associated with FOMC statements about the future path of the federal funds rate. Their results demonstrated that forward guidance is effective, and have since been updated and confirmed for the U.S. and other countries by, among others, Claus Brand, Daniel Buncic, and Jarkko Turunen (2010); Stefania D'Amico and Mira Farka (2011); Jeffrey Campbell and others (2012); Matteo Leombroni and others (2017); and Swanson (2018).

An equally large and growing body of literature finds that the Fed's LSAPs have had economically and statistically significant effects on longerterm bond yields. These analyses range from high-frequency event studies of the United States (Gagnon and others 2011; Krishnamurthy and VissingJorgensen 2011) and the United Kingdom (Joyce and others 2011) to historical studies of "Operation Twist" in 1961 (Swanson 2011) to lowerfrequency, monthly studies of U.S. Treasury yields and spreads vis-à-vis the Treasury's supply from 1919 to 2008 (Krishnamurthy and Vissing-Jorgensen 2012) to monthly no-arbitrage term structure models with quantity effects (Greenwood and Vayanos 2012; Hamilton and Wu 2012). Swanson (2011) and Williams (2013) survey these estimates, but a common benchmark is that $\$ 600$ billion in LSAPs causes the 10 -year Treasury note yield to fall about 15 basis points.

Swanson (2018) estimates the effects of both forward guidance and LSAP announcements on financial markets and finds that they are roughly as effective as changes in the federal funds rate in normal times. Table 1 


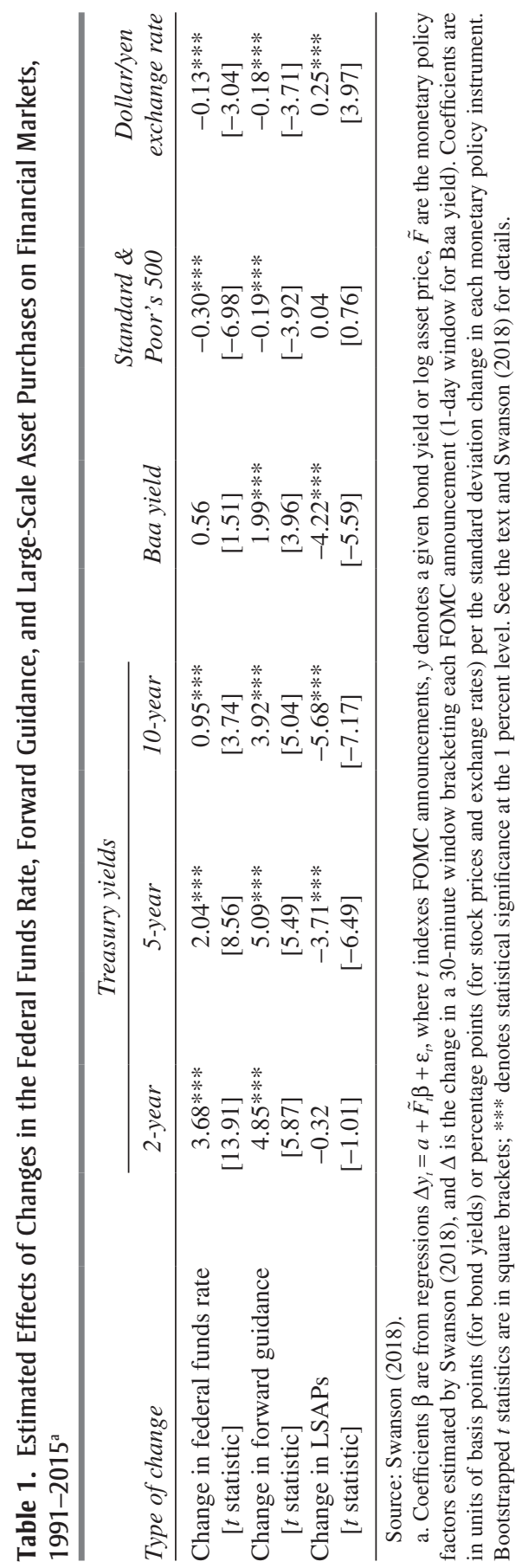


summarizes the results. ${ }^{1}$ The table's first four columns report the effects of changes in the federal funds rate, forward guidance, and LSAPs on 2-, 5-, and 10-year Treasury yields and Moody's index of Baa-rated corporate bond yields, in units of basis points per standard deviation change in the policy instrument. ${ }^{2}$ Thus, the effect of an increase of 1 standard deviation in the federal funds rate is about 3.7 basis points on the 2-year Treasury yield; for forward guidance, the effect on the 2-year yield is bigger, about 4.9 basis points per standard deviation change; and for LSAPs, the effect is smaller, about -0.3 basis points, and not statistically significant. LSAPs primarily affect longer maturities and the federal funds rate affects shorter maturities, but overall the three policies have effects on yields that are broadly comparable in magnitude. This is further supported by the last two columns of table 1, which report the effects on the Standard \& Poor's 500 and the dollar/yen exchange rate, in units of percentage points per standard deviation change in each policy instrument. The effects of all three policies have the signs one would expect—higher interest rates imply lower stock prices and dollar appreciation - and are roughly comparable in magnitude. These results all suggest that forward guidance and LSAPs are effective monetary policy tools; in fact, they are about as effective as changes in the federal funds rate in normal times.

Looking beyond asset prices, some researchers have used detailed bank-level data to show that LSAPs have significant effects on bank lending. Alexander Rodnyansky and Olivier Darmouni (2017) show, via a differences-in-differences analysis of quarterly U.S. bank-level data, that banks that owned more LSAP-eligible mortgage-backed securities increased business lending in response to the Fed's LSAPs. Marco Di Maggio, Amir Kermani, and Christopher Palmer (2016) apply a similar differences-indifferences analysis to monthly loan-level U.S. mortgage originations to show that conforming (eligible for purchase by Fannie Mae and Freddie Mac)

1. Some researchers, such as Campbell and others (2012), distinguish between two types of forward guidance announcements by the Federal Reserve-those that convey information about the economy versus those that only convey information about monetary policy. Swanson (2018) does not try to separately identify these two types of forward guidance announcements, so the estimates given in table 1 represent an average forward guidance announcement effect.

2. The standard deviation of surprise changes in the federal funds rate is 8.8 basis points, measured over the period from 1991 to 2008; the standard deviation of surprise changes in forward guidance is 6 basis points in the one-year-ahead expected federal funds rate, as measured by eurodollar futures from 1991 to 2015; and the standard deviation of a surprise LSAP announcement is about $\$ 250$ billion in long-term bond purchases, measured over the period 2009-15. See Swanson (2018) for details. 
mortgage originations increased in response to the Fed's LSAPs. ${ }^{3}$ Michael Koetter, Natalia Podlich, and Michael Wedow (2017) analyze quarterly German bank-level, security-by-security data to show, via differences-indifferences, that German banks that held more eligible securities for the European Central Bank's Securities Markets Programme increased their lending in response to the program. Thus, the effects of LSAPs extend beyond just a high-frequency change in financial market prices.

Some researchers have argued that, even though LSAPs have had a significant effect on financial markets on impact, those effects have tended to die out over time (Greenlaw and others 2018). The monthly and quarterly bank-lending studies described above provide evidence against this viewafter all, if the financial market effects rapidly died out, why would banks increase their lending over subsequent months and quarters? Swanson (2018) also studies the persistence of financial market responses to LSAP announcements and finds that they were very persistent, with the exception of the very large and perhaps special "QE1" (first quantitative easing) announcement on March 18, 2009. On that date, bond yields fell dramatically in response to the FOMC announcement, but then began to rise over subsequent weeks, as the Dow Jones Industrial Average gained over 13 percent and the Fed's bank stress tests, released May 7, 2009, turned out better than markets expected; thus, the markets' behavior in those weeks may not be representative of the longer-run effects of LSAPs more generally. Figure 1 reproduces two graphs from Swanson (2018) that show a tendency for the effects of LSAPs to die out when the March 18, 2009, observation is included (left panel), but not when that one very influential announcement is excluded (right panel).

To sum up thus far, there is a great deal of evidence that both forward guidance and LSAPs are effective monetary policy tools-in fact, they are about as effective as changes in the federal funds rate in normal times. There is also very strong evidence that LSAPs have affected bank lending. Although some have argued that the effects of LSAPs are not persistent, this view seems to be driven by one very influential FOMC announcement on March 18, 2009, which may have been special for a number of reasons. Excluding this one announcement, the estimated effects of LSAPs on financial markets have been essentially completely persistent.

3. To be precise, Rodnyansky and Darmouni (2017) and Di Maggio and others (2016) find that the Fed's LSAP purchases of mortgage-backed securities had a significant effect on bank lending; the Fed's purchases of long-term Treasury securities during the QE2 program did not seem to have such an effect. 
Figure 1. Estimated Effects of LSAPs on the 10-Year, Zero-Coupon Treasury Yield ${ }^{\mathrm{a}}$

\section{Effect of LSAPs on 10-year Treasury yield}

Coefficient $\gamma_{h}$

(basis points per standard deviation)

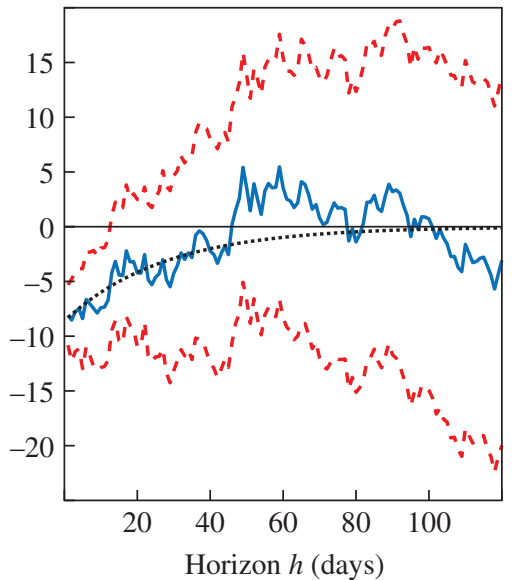

Effect of LSAPs on 10-year Treasury yield, excluding March 18, 2009

Coefficient $\gamma_{h}$

(basis points per standard deviation)

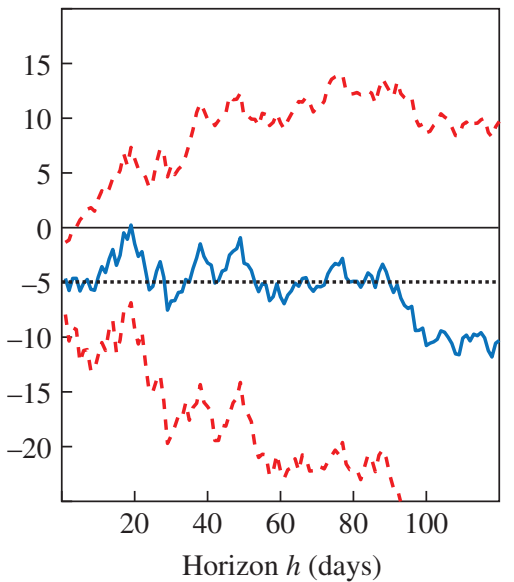

Source: Swanson (2018).

a. LSAPs $=$ large-scale asset purchases. Estimated effects of LSAPs on the 10-year, zero-coupon Treasury yield, for different horizons $h$ from 1 to 120 business days, including and excluding the influential March 18, 2009, "QE1" announcement. Estimated coefficients $\hat{\gamma}_{h}$ (solid lines) and bootstrapped \pm 1.96 -standard error bands (dashed lines) are from regressions $y_{t-1+h}-y_{t-1}=\gamma_{h}-F_{t}+\varepsilon^{(h)}$. Restricted coefficient estimates $\gamma_{h}=\mathrm{ae}^{-b(h-l)}$ (dash-dotted lines) are from the same set of regressions estimated jointly via nonlinear least squares. See the text and Swanson (2018) for additional details.

\section{The Federal Reserve Was Not Very Constrained by the ZLB from 2008 to 2015}

The second main observation is that, during the 2008-15 ZLB period, the Federal Reserve was not very constrained in its ability to affect medium- and longer-term interest rates and the economy. A quick way to see this is shown in figure 2, which plots the federal funds rate and 1-, 2-, 5-, and 10-year, zero-coupon Treasury yield from 2007 to 2017. ${ }^{4}$ Although the federal funds rate was virtually zero and never changed from December 2008 to November 2015, the 2-year Treasury yield—which is

4. Zero-coupon yields are from the data set given by Gürkaynak, Sack, and Wright (2007), available from the Federal Reserve Board's website at https://www.federalreserve. gov/pubs/feds/2006/200628/200628abs.html. 
Figure 2. The Federal Funds Rate and 1-, 2-, 5-, and 10-Year Zero-Coupon Treasury Yields, 2007-18

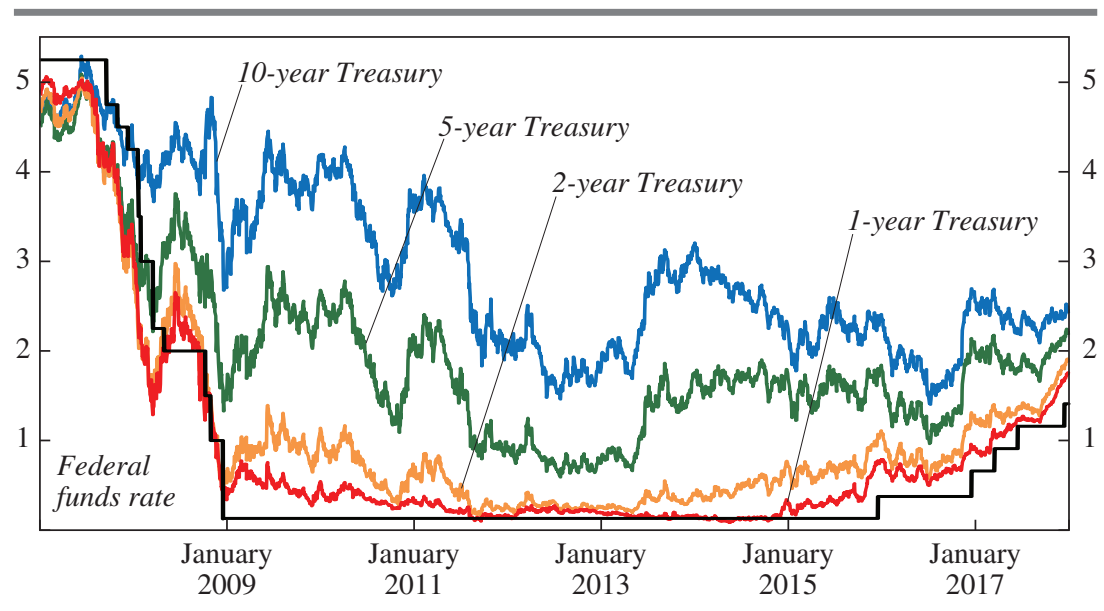

Sources: Author's update of figure from Swanson and Williams (2014), using yield curve data from Gürkaynak, Sack, and Wright (2007).

a. See the text for details.

a better measure of the overall stance of monetary policy, as can be seen in equation 2-averaged about 55 basis points during this period and fluctuated substantially over time, ranging between 16 and 140 basis points and moving up or down every day in response to macroeconomic data releases, FOMC announcements, and other news.

Swanson and Williams (2014) formalize this point by estimating how responsive the 2-year and other Treasury yields are to major macroeconomic announcements, relative to a benchmark sample from 1990 to 2000, when the ZLB was not a constraint. That is, they run daily-frequency regressions of the form

$$
\Delta y_{t}=\gamma^{\tau}+\delta^{\tau} \beta X_{t}+\varepsilon_{t},
$$

where $t$ indexes business days, $\Delta y_{t}$ is the one-day change in the 2-year Treasury yield (or other yield), $X_{t}$ is an $n$-dimensional vector of major macroeconomic data releases that day (such as nonfarm payrolls, the Consumer Price Index, and GDP), $\beta$ is an $n$-dimensional vector of parameters containing the normal responsiveness of the 2-year Treasury yield to each of those releases, and the parameters $\gamma^{\tau}$ and $\delta^{\tau}$ are scalars that vary over time, with $\delta^{\tau}$ normalized to a unit mean over the baseline sample from 
Figure 3. Time-Varying Sensitivity Coefficients $\delta^{\tau}$ from Regression Equation 3 Applied to Two-Year and Five-Year Treasury Yields ${ }^{a}$

Two-year Treasury yield sensitivity to news

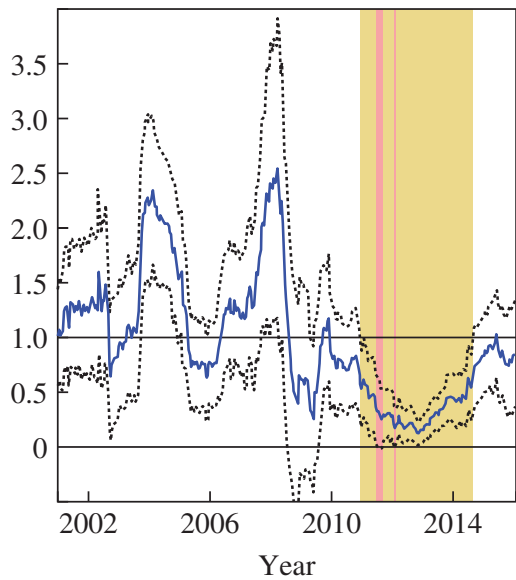

Five-year Treasury yield sensitivity to news

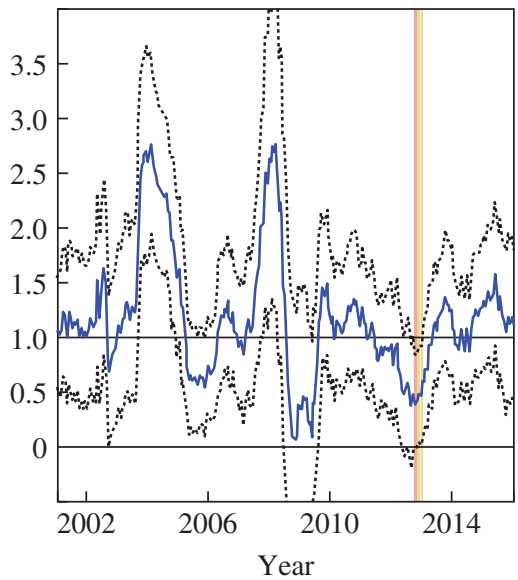

Source: Author's update of figures from Swanson and Williams (2014).

a. Dotted lines denote heteroskedasticity-consistent \pm 2 -standard error bands, $\delta^{\tau}=1$ corresponds to normal Treasury sensitivity to news, and $\delta^{\tau}=0$ corresponds to complete insensitivity. Light shaded regions denote $\delta^{\tau}$ significantly less than 1 ; darker shaded regions denote $\delta^{\tau}$ significantly less than 1 and not significantly different from 0 . See the text and Swanson and Williams (2014) for additional details.

1990 to $2000 .^{5}$ Thus, the scalar $\delta^{\tau}$ captures the overall sensitivity of the 2-year Treasury yield to major macroeconomic announcements around a given date, with $\delta^{\tau}=1$ corresponding to normal sensitivity to news and $\delta^{\tau}=0$ to complete insensitivity to news.

Figure 3 plots the time-varying sensitivity coefficients $\delta^{\tau}$ from regression equation 3 for the 2- and 5-year Treasury yields from 2001 to 2015. The solid line in each panel plots the estimated value of $\delta^{\tau}$ on each date $\tau$, while the dotted lines depict heteroskedasticity-consistent \pm 2 -standard error bands. The horizontal lines are drawn at 0 and 1 as benchmarks for

5. On most days, there is no news about a given macroeconomic statistic; thus, if the first column of $X$ corresponds to nonfarm payrolls, then that column would be zero on every date $t$ except once per month, when the nonfarm payrolls data are released. On each nonfarm payrolls announcement date, the first column of $X_{t}$ contains the surprise component of the announcement - that is, the actual released value of nonfarm payrolls less the median market expectation from the day before. The scalar parameters $\gamma^{\tau}$ and $\delta^{\tau}$ are estimated over rolling 250 -business-day windows, while the vector $\beta$ is fixed over the whole sample. See Swanson and Williams (2014) for details. 
comparison, corresponding to the cases of complete insensitivity to news and normal sensitivity, respectively. Light shaded regions denote periods when the estimated value of $\delta^{\tau}$ is significantly less than unity; in addition, if the hypothesis that $\delta^{\tau}=0$ cannot be rejected, then the region is shaded darker. Thus, darker shaded regions correspond to periods in which the Treasury yield was essentially insensitive to news, while lighter shaded regions correspond to periods when the yield was partially-but not completely-unresponsive to news.

The left panel of figure 3 shows that, from 2008 to 2011, the 2-year Treasury note yield's sensitivity to news was essentially never significantly less than normal. From 2011 to mid-2014, the 2-year yield's sensitivity did drop below normal, but was still greater than zero, except for two very brief periods near the end of 2011. Thus, despite the fact that the federal funds rate (and other short-term interest rates) were completely constrained by the ZLB throughout the period 2009-15, the 2-year Treasury yield continued to respond substantially to macroeconomic news. The 5-year Treasury yield, in the figure's right panel, was essentially never constrained by the ZLB during this period.

Carlos Carvalho, Eric Hsu, and Fernanda Nechio (2016) examine the effects of Federal Reserve communications on medium- and longer-term interest rates and come to the same conclusion. These researchers use textual analysis of newspaper articles in Factiva around each FOMC announcement to measure the perceived change in the Fed's "hawkishness" or "dovishness." They run regressions of medium- and longer-term Treasury yields on this measure of Fed communication, analogous to equation 3 above. Carvalho, Hsu, and Nechio (2016) show that their text-based measure of Fed communication had economically and statistically significant effects on 2-, 5-, and 10-year Treasury yields throughout the 2008-15 ZLB period, with results that are similar to those of Swanson and Williams (2014) and figure 3, above. Their results provide direct evidence that the Fed was never very constrained in its ability to move medium- and longerterm interest rates throughout the period 2008-15.

Additional indirect evidence supporting this conclusion is provided by the macroeconomic vector autoregression (VAR) studies done by Jing Cynthia Wu and Fan Dora Xia (2016) and by Davide Debortoli, Jordi Galí, and Luca Gambetti (2018). Wu and Xia (2016) use an affine term structure model to estimate a "shadow federal funds rate" during the ZLB period-that is, a hypothetical negative federal funds rate that summarizes the effects of the Fed's unconventional monetary policies on the yield 
curve at each date. They estimate a VAR for output, inflation, and the shadow federal funds rate from 1960 to 2013, where the shadow federal funds rate is set equal to the federal funds rate in the pre-ZLB period, and find no evidence of a structural break in the VAR between the preZLB and ZLB periods. They conclude that the Fed was able to affect the macroeconomy during the ZLB period in much the same way as it did before, albeit through unconventional rather than conventional monetary policy.

Debortoli, Galí, and Gambetti (2018) estimate VAR models with timevarying parameters and come to the same conclusion. They find no evidence of a change in the U.S. economy's responses to a technology shock or a demand shock in the pre-ZLB and ZLB periods. They also show that their methods would detect clear evidence of such a change if the economy followed a standard New Keynesian model and monetary policy was conducted by a Taylor-type interest rate rule that faced a ZLB constraint. They conclude that the Fed's unconventional monetary policies during the ZLB period were essentially a perfect substitute for changes in the federal funds rate.

Finally, Arsenios Skaperdas (2017) performs a multisector analysis of the U.S. economy from 1970 to 2012 and from 1988 to 2012. He ranks sectors by their interest rate sensitivity in the pre-2008 period, with sectors like construction, mining, and transportation being the most interestsensitive and health care and services the least sensitive. If interest rates were kept artificially higher than normal by the ZLB in the period 2008-15, then the interest-rate-sensitive sectors of the economy should have performed relatively worse than they did after the previous 1990-91 and 2001-3 recessions. He shows that this was not the case; interest-ratesensitive sectors performed about as well after the period 2007-9 as they did after previous recessions. Like Wu and Xia (2016) and Debortoli, Galí, and Gambetti (2018), he concludes that the Fed's forward guidance and LSAPs during the ZLB period were able to lower medium- and longerterm interest rates in much the same way as in previous recessions.

To sum up the results of this section, the Fed was not very constrained in its ability to affect medium- and longer-term interest rates throughout the ZLB period. Moreover, explicit tests for a structural break or change in macroeconomic behavior in 2009 fail to find any evidence that the economy behaved differently during the ZLB period than before, suggesting that the Fed's unconventional monetary policies during this period were a close substitute for changes in the federal funds rate. 


\section{The Risks of Being Constrained by the ELB in the Future Are Overstated}

Finally, the risks of the Fed being significantly constrained by the ELB in the future are typically greatly overstated. There are three main reasons for this overstatement. First, the federal funds rate must be constrained by the ELB for several quarters, rather than just one quarter, to have a noticeable effect on the economy. Second, central banks in Europe have demonstrated that the ELB is substantially below zero; at least -0.75 percent, and probably a bit below -1 percent. And third, even in those rare cases when the federal funds rate is at the ELB for several quarters, the Fed has alternative monetary policy tools available to it, as discussed above.

Lawrence Christiano, Martin Eichenbaum, and Sergio Rebelo (2011) study the effects of fiscal policy in a standard, medium-scale New Keynesian model at the ZLB. They show that when the ZLB constrains the short-term interest rate for 8 or 12 quarters, the fiscal multiplier is substantially larger than normal because the standard monetary policy response to the fiscal shock is shut down. However, they also show that when the ZLB binds for only four quarters, then the fiscal multiplier is not any larger than normal (Christiano, Eichenbaum, and Rebelo 2011, n. 11). The intuition for this result is straightforward; according to equation 2 above, the output gap today is determined by the entire expected path of the federal funds rate, not just the federal funds rate today. If the federal funds rate is only constrained by the ZLB for a few periods, then the effect on the sum in equation 2 is relatively small, and the effect on the economy is correspondingly small. This helps to clarify that the ZLB is not a significant constraint on the economy unless it binds for several quarters (for example, eight or more).

In addition, several central banks in Europe have shown that the ELB is substantially less than zero. In December 2014, the Swiss National Bank lowered the target for its short-term policy rate to -0.25 percent, followed by an additional cut to -0.75 percent in January 2015, where it has since remained. In Sweden, the Riksbank lowered its short-term policy rate to -0.1 percent in February 2015, followed by several additional rate cuts that brought it down to -0.5 percent in February 2016, where it has since remained. For the euro area, the European Central Bank reduced the lower end of its policy rate corridor, the deposit facility rate, to -0.1 percent in June 2014, followed by several additional cuts that lowered it to -0.4 percent in March 2016, where it has since remained; importantly, money market interest rates have traded near the lower end of the European Central Bank's 
corridor throughout this period. In Denmark, the Nationalsbank lowered its deposit rate to -0.2 percent in July 2012 and eventually reduced it to -0.75 percent in February 2015, although it has since raised it to -0.65 percent. All these central banks have maintained negative policy rates for several years with no widespread conversion of deposits into currency. ${ }^{6}$ Evidently, the ELB in Europe is substantially below zero, at least -0.75 percent and probably a bit below -1 percent.

A concern that is sometimes raised regarding negative policy rates is that they might not pass through to other interest rates in the economy. For retail deposit rates, there is some evidence that this is the case (Eggertsson, Juelsrud, and Wold 2017). However, Rafael De Rezende (2017) finds no difference in the pass-through from changes in the Swedish policy rate to Swedish government bond yields during the negative policy rate regime relative to the period before. Rima Turk (2016) shows that policy rate cuts in Sweden and Denmark passed through to money market rates and bank loan interest rates in those countries to the same extent during the negative interest rate regime as before, and Turk (2016) and Daniel Gros and others (2016) report that banks increased a variety of fees on retail customers as a substitute for charging those depositors an explicitly negative interest rate. Selva Demiralp, Jens Eisenschmidt, and Thomas Vlassopoulos (2017) analyze quarterly, individual, euro area bank balance sheet data and find that banks increased lending in response to policy rate cuts in the negative policy rate regime by at least as much as before. ${ }^{7}$ Overall, the pass-through from negative monetary policy rates to other financial market rates does not seem to be inhibited by the policy rate being negative. ${ }^{8}$

6. This is especially remarkable given that the European Central Bank offers $€ 500$ denomination notes and the Swiss National Bank offers CHF1,000 notes.

7. To be precise, Demiralp and others (2017) compare more versus less retail-depositfunded banks. They show that more retail-deposit-funded banks, which are hit harder by negative policy rates, were relatively more likely to increase lending, reduce reserves, and increase government securities holdings in response to interest rate cuts in the negative policy rate regime than before.

8. A second, related concern regarding negative policy rates is that they might depress bank profitability, which in turn might reduce bank lending or have other deleterious effects on the economy. However, because retail deposit rates are less than the policy rate, this argument applies to low positive interest rates just as much as it applies to negative rates; thus, if the Fed were willing to lower the federal funds rate from 0.75 percent to 0 , it should be essentially just as willing to lower the funds rate into negative territory. In addition, Lopez, Rose, and Spiegel (2018), Turk (2016), and Gros and others (2016) find no decrease in bank profitability in the negative policy rate regimes in Europe and Japan, because banks' increased fee income and capital gains offset their retail deposit interest expenses. 
Together, these two observations- that the ELB is significantly less than zero and must bind for eight quarters or more to have noticeable effects on the economy-imply that previous estimates of the risks of the Fed facing a significant ELB constraint in the future are typically greatly overstated. For example, Michael Kiley and John Roberts (2017) define the ELB to be 0 percent-a ZLB - and then simulate a structural model to count the number of quarters in which the federal funds rate is less than or equal to zero, even if this episode lasts for just one quarter. Reifschneider and Williams (2000) and Williams (2009) perform calculations very similar to those of Kiley and Roberts (2017), albeit with a less pessimistic shock distribution. ${ }^{9}$ Obviously, these calculations greatly overstate the number of times the short-term interest rate drops below a more realistic ELB of -0.75 percent for eight quarters or more, which is the economically relevant question.

Even in those rare cases when the nominal interest rate does fall that far for that long, the simple calculations done by Williams (2009) and Kiley and Roberts (2017) ignore the existence of unconventional monetary policies such as forward guidance and LSAPs. As shown in the previous two sections, there is extensive evidence that these policies are effective and provide a close substitute for changes in the federal funds rate.

\section{Caveats}

Although the observations above are supported by a wide variety of papers, data sets, and methods, there are still a few caveats to keep in mind. First, in a very severe ELB scenario, in which the federal funds rate is expected to be at the lower bound for more than eight quarters, the effectiveness of forward guidance could become much lower than in the past. This almost happened in 2012 (see figure 3), when financial markets expected the ZLB to be a constraint for long enough that the two-year Treasury yield's sensitivity to news fell substantially. In the end, the two-year yield's sensitivity never fell to zero, but if such a severe ELB constraint arose in the future, the two-year Treasury yield could cease to be a viable instrument of forward guidance. In principle, the Fed could work around this constraint by extending its forward guidance to even longer horizons, but in practice the Federal Reserve's chair may have difficulty committing his or

9. Kiley and Roberts (2017) draw shocks from the empirical distribution of shocks to the U.S. economy from 1970 to 2015, which implies that the United States will face another financial crisis and Great Recession every 40 to 45 years, on average. 
her successor to a given path for the federal funds rate. However, even in such a dire situation as this, the Fed still has the ability to conduct LSAPs and influence financial markets and the economy through that channel. As shown in table 1 above, LSAPs have effects that are similar in magnitude to those of the federal funds rate and forward guidance, but operate substantially farther out along the yield curve.

Second, there may be political constraints that make it difficult for the Fed to use LSAPs and negative interest rates. During the 2008-15 U.S. ZLB period, LSAPs seemed to be poorly understood by the public and in many cases evoked strong negative reactions, such as being called "almost treasonous" by Texas governor Rick Perry (Wearden 2011). And even though the Fed never used negative interest rates in 2008-15, the idea evokes similarly vehement opposition from many commercial and investment bankers, presumably due to fears about bank profitability; for example, Deutsche Bank chief executive John Cryan argued that they have "fatal consequences," Allianz chief economic adviser Mohamed El-Erian called them an "insane experiment," Janus Capital financial manager Bill Gross said that "capitalism . . . cannot function" with them, Barclays CEO Jes Staley stated that "they are not helpful," and BlackRock chief executive Larry Fink told shareholders they bring "potentially dangerous financial and economic consequences" (Cox 2016; Flynn 2016; Alban 2016; Wenik 2016). Given this opposition, it may be more difficult for the Fed to pursue these policies than the literature surveyed above would suggest.

\section{Conclusions}

The Federal Reserve is not significantly constrained by the lower bound on nominal interest rates. This conclusion is supported by three main observations. First, the Fed's forward guidance and LSAPs are effective monetary policy tools, about as effective as changes in the federal funds rate in normal times. Second, during the 2008-15 U.S. ZLB period, the Fed was not significantly constrained in its ability to affect mediumand longer-term interest rates and the economy. And third, the risks of the Fed being significantly constrained by the ELB in the future are typically greatly overstated. These observations are supported by dozens of papers analyzing a variety of countries and data sets and using a wide variety of methods, ranging from high-frequency financial market responses to no-arbitrage term structure models to macroeconomic VARs to quarterly bank-level lending data. Although there are a few caveats to keep in mind, the overall conclusion is robust to these concerns. 


\section{References}

Alban, Jennifer. 2016. "Bill Gross Steps Up Criticism of Fed, Central Banks for Zero Rates." Reuters Business News, August 31.

Brand, Claus, Daniel Buncic, and Jarkko Turunen. 2010. "The Impact of ECB Monetary Policy Decisions and Communication on the Yield Curve." Journal of the European Economic Association 8: 1266-98.

Campbell, Jeffrey, Charles Evans, Jonas Fisher, and Alejandro Justiniano. 2012. "Macroeconomic Effects of Federal Reserve Forward Guidance." Brookings Papers on Economic Activity, Spring, 1-53.

Carvalho, Carlos, Eric Hsu, and Fernanda Nechio. 2016. "Measuring the Effect of the Zero Lower Bound on Monetary Policy." Federal Reserve Bank of San Francisco Working Paper 2016-06.

Christiano, Lawrence, Martin Eichenbaum, and Sergio Rebelo. 2011. "When Is the Government Spending Multiplier Large?” Journal of Political Economy 119: 78-121.

Cox, Jeff. 2016. "Deutsche CEO: Negative Rates Have 'Fatal Consequences.'” CNBC, August 25.

D'Amico, Stefania, and Mira Farka. 2011. "The Fed and the Stock Market: An Identification Based on Intraday Futures Data." Journal of Business and Economic Statistics 29: 126-37.

Debortoli, Davide, Jordi Galí, and Luca Gambetti. 2018. "On the Empirical (Ir) Relevance of the Zero Lower Bound Constraint.” Barcelona GSE Working Paper 1013.

Demiralp, Selva, Jens Eisenschmidt, and Thomas Vlassopoulos. 2017. "Negative Interest Rates, Excess Liquidity, and Bank Business Models: Banks' Reaction to Unconventional Monetary Policy in the Euro Area." Unpublished manuscript, European Central Bank.

De Rezende, Rafael. 2017. "The Interest Rate Effects of Government Bond Purchases Away from the Lower Bound." Journal of International Money \& Finance 74: 165-86.

Di Maggio, Marco, Amir Kermani, and Christopher Palmer. 2016. "How Quantitative Easing Works: Evidence on the Refinancing Channel.” NBER Working Paper 22638. Cambridge, Mass.: National Bureau of Economic Research.

Eggertsson, Gauti, Ragnar Juelsrud, and Ella Getz Wold. 2017. “Are Negative Nominal Interest Rates Expansionary?” NBER Working Paper 24039. Cambridge, Mass.: National Bureau of Economic Research.

Eggertsson, Gauti, and Michael Woodford. 2003. "The Zero Interest-Rate Bound and Optimal Monetary Policy." Brookings Papers on Economic Activity, Spring, 139-235.

Flynn, Finbarr. 2016. "Negative Interest Rates Confront Growing Chorus of CEO Critics.” Bloomberg, April 27.

Gagnon, Joseph, Matthew Raskin, Julie Remache, and Brian Sack. 2011. "The Financial Market Effects of the Federal Reserve's Large-Scale Asset Purchases." International Journal of Central Banking 7: 3-43. 
Greenlaw, David, James Hamilton, Ethan Harris, and Kenneth West. 2018. "A Skeptical View of the Impact of the Fed's Balance Sheet." NBER Working Paper 24687. Cambridge, Mass.: National Bureau of Economic Research.

Greenwood, Robin, and Dimitri Vayanos. 2012. "Bond Supply and Excess Bond Returns." Review of Financial Studies 27: 663-713.

Gros, Daniel, Christophe Blot, Paul Hubert, Maria Demertzis, and Guntram Wolff. 2016. "How Do Low and Negative Interest Rates Affect Banks' Activity and Profitability in the Euro Area?" European Parliament Monetary Dialogue 2016-04, November.

Gürkaynak, Refet, Brian Sack, and Eric Swanson. 2005. "Do Actions Speak Louder than Words? The Response of Asset Prices to Monetary Policy Actions and Statements." International Journal of Central Banking 1: 55-93.

Gürkaynak, Refet, Brian Sack, and Jonathan Wright. 2007. "The U.S. Treasury Yield Curve: 1961 to the Present." Journal of Monetary Economics 54: 2291-2304.

Hamilton, James, and Jing Cynthia Wu. 2012. "The Effectiveness of Alternative Monetary Policy Tools in a Zero Lower Bound Environment." Journal of Money, Credit, and Banking 44: 3-46.

Joyce, Michael, Ana Lasaosa, Ibrahim Stevens, and Matthew Tong. 2011. "The Financial Market Impact of Quantitative Easing in the United Kingdom." International Journal of Central Banking 7: 113-61.

Kiley, Michael, and John Roberts. 2017. "Monetary Policy in a Low Interest Rate World." Brookings Papers on Economic Activity, Spring 2017, 317-72.

Koetter, Michael, Natalia Podlich, and Michael Wedow. 2017. "Inside Asset Purchase Programs: The Effects of Unconventional Policy on Bank Competition." European Central Bank Working Paper 2017.

Krishnamurthy, Arvind, and Annette Vissing-Jorgensen. 2011. "The Effects of Quantitative Easing on Interest Rates: Channels and Implications for Policy." Brookings Papers on Economic Activity, Fall, 215-65.

. 2012. "The Aggregate Demand for Treasury Debt." Journal of Political Economy 120: 233-67.

Krugman, Paul. 1998. "It's Baaack! Japan's Slump and the Return of the Liquidity Trap." Brookings Papers on Economic Activity, Fall, 137-187.

Leombroni, Matteo, Andrea Vedolin, Gyuri Venter, and Paul Whelan. 2017. "Central Bank Communication and the Yield Curve." Unpublished manuscript, Boston University.

Lopez, Jose, Andrew Rose, and Mark Spiegel. 2018. "Why Have Negative Interest Rates Had Such a Small Effect on Bank Performance? Cross Country Evidence." NBER Working Paper 25004. Cambridge, Mass.: National Bureau of Economic Research.

Reifschneider, David, and John Williams. 2000. "Three Lessons for Monetary Policy in a Low Inflation Era." Journal of Money, Credit, and Banking 32: 936-66.

Rodnyansky, Alexander, and Olivier Darmouni. 2017. "The Effects of Quantitative Easing on Bank Lending Behavior.” Review of Financial Studies 30: 3858-87. 
Skaperdas, Arsenios. 2017. "How Effective Is Monetary Policy at the Zero Lower Bound? Identification through Industry Heterogeneity." Federal Reserve Board Finance and Economics Discussion Series 2017-073.

Swanson, Eric. 2011. "Let's Twist Again: A High-Frequency Event-Study Analysis of Operation Twist and Its Implications for QE2." Brookings Papers on Economic Activity, Spring, 151-88.

. 2018. "Measuring the Effects of Federal Reserve Forward Guidance and Asset Purchases on Financial Markets." NBER Working Paper 23311. Cambridge, Mass.: National Bureau of Economic Research.

Swanson, Eric, and John Williams. 2014. "Measuring the Effect of the Zero Lower Bound on Medium- and Longer-Term Interest Rates." American Economic Review 104: 3154-85.

Turk, Rima. 2016. "Negative Interest Rates: How Big a Challenge for Large Danish and Swedish Banks?" IMF Working Paper WP/16/198.

Wearden, Graeme. 2011. "Rick Perry: 'Quantitative Easing Akin to Treason."” The Guardian, August 11.

Wenik, Ian. 2016. "Barclays (BCS) CEO Staley: 'Negative Interest Rates Are Not Helpful." The Street.com, September 12.

Williams, John. 2009. "Heeding Daedalus: Optimal Inflation and the Zero Lower Bound." Brookings Papers on Economic Activity, Fall, 1-37.

. 2013. "Lessons from the Financial Crisis for Unconventional Monetary Policy." Paper prepared for panel discussion at NBER Conference on Lessons from the Financial Crisis for Monetary Policy, October 18. http://www.frbsf.org/ our-district/press/presidents-speeches/williams-speeches/2013/october/researchunconventional-monetary-policy-?nancial-crisis.

Wu, Jing Cynthia, and Fan Dora Xia. 2016. "Measuring the Macroeconomic Impact of Monetary Policy at the Zero Lower Bound." Journal of Money, Credit and Banking 48: 253-91. 